\title{
KONSEP DIRI PELAJAR YANG BERPROFESI SEBAGAI PESINDHEN SEKOLAH MENENGAH DI KOTA KEDIRI
}

\author{
Abdul Mukhlis \\ Bimbingan Konseling, Fakultas Keguruan dan Ilmu Pendidikan, Universitas Nusantara PGRI Kediri \\ abdulmukhlis.galery@gmail.com \\ Rosalia Dewi Nawantara, dan Laelatul Arofah \\ Bimbingan Konseling, Fakultas Keguruan dan Ilmu Pendidikan, Universitas Nusantara PGRI Kediri \\ rosaliadewi@unpkediri.ac.id\&arofahlaila@unpkediri.ac.id
}

\begin{abstract}
Abstrak
Kediri memiliki budaya tradisional yang beragam, yaitu wayang kulit, ludruk, campursari, tayub dan semua kesenian tersebut tidak lepas dari seorang pesindhen. Di Kediri terdapat pesindhen muda yang masih duduk dibangku sekolah menengah. Penelitian ini bertujuan untuk mengetahui konsep diri pelajar yang berprofesi sebagai pesindhen dalam memaknai diri terhadap profesinya dan lingkungan sosial memaknai pelajar yang berprofesi sebagai pesindhen di Kota Kediri.Penelitian ini adalah penelitian yang besifat kualitatif. Penelitian yang digunakan yaitu penelitian kualitatif deskriptif. Penelitian kualitatif deskriptif adalah berupa penelitian dengan metode atau pendekatan studi kasus (case study), observasi partisipan, wawancara mendalam, studi dokumentasi, dan menggunakan materi audio visual. Hasil penelitian ini yaitu menjadi pesindhen merupakan profesi yang unik, sulit untuk ditekuni, dan tidak semua orang mampu untuk menjadi seorang sindhen. Pesindhen pelajar ini menekuni profesinya berdasarkan kemauan diri pribadi serta adanya dorongan untuk belajar seni tradisional oleh karena itu mereka merasa senang, nyaman dan bangga dengan profesinya. Lingkungan sosial memaknai profesi pesindhen sebagai profesi yang positif.
\end{abstract}

Kata Kunci: fenomenologi, konsep diri, pesindhen pelajar

\begin{abstract}
Kediri has a diverse traditional culture, namely wayang kulit, ludruk, campursari, tayub and all of these arts are inseparable from a pesindhen. In Kediri there is a young pesindhen who is still in the middle school. This study aims to determine the self-concept of students who work as pesindhen in interpreting themselves to their profession and social environment interpreting students who work as pesindhen in Kediri City. This research is a qualitative study. The research used is descriptive qualitative research. Descriptive qualitative research is in the form of research with case study methods or approaches, participant observation, in-depth interviews, documentation studies, and using audio-visual material. The results of this study are being a pesindhen is a unique profession, difficult to pursue, and not everyone can afford to become a sindhen. Pesindhen students are pursuing their profession based on personal will and there is an encouragement to learn traditional arts, therefore they feel happy, comfortable and proud of their profession. The social environment defines the pesindhen profession as a positive profession..
\end{abstract}

Keywords:phenomenology, self concept, student pesindhen 


\section{PENDAHULUAN}

Budaya Jawa terkenal akan kesenian yang memiliki harmonisasi instrumen gamelan yang indah serta berkaitan dengan sejarah kerajaan-kerajaan dimasa lalu atau cerita peninggalan nenek moyang. Kebudayaan tersebut bisa dilihat dari berbagai kesenian yaitu wayang kulit, wayang krucil, wayang beber, wayang orang, ludruk, ketoprak, campursari, tayub, jaranan dan masih banyak lagi, semua ini tidak lepas dari seorang penyanyi yang disebut sindhen. Sindhen juga disebut waranggana "wara" berarti seseorang berjenis kelamin wanita, dan "hanggana" berarti sendiri. Sindhen adalah sebutan bagi wanita yang bernyanyi mengiringi orkestra gamelan, mamakai pakaian kebaya lengkap dengan selendang atau orang jawa menyebutnya "sampur"yang umumnya sebagai penyanyi yang serba bisa. Sindhen yang baik harus mempunyai pengetahuan luas dan keahlian vokal yang baik serta kemampuan untuk menyanyikan 'tembang" atau lagu. Pada pertunjukan wayang saat ini sindhen bisa mencapai delapan hingga sepuluh orang bahkan lebih untuk pergelaran yang sifatnya spektakuler.

Di wilayah Kediri Jawa Timur profesi sindhen telah ditekuni oleh beberapa wanita muda yang memiliki ketertarikan akan keindahan budaya kesenian jawa, pada umumnya mereka belajar mengembangkan atau menyanyikan lagu jawa yang dilatih oleh seorang dalang pewayangan daerah mereka, dan setelah itu mereka di didik untuk belajar cengkok suara "gendhing" yang terkesan halus dan lembut. Hasil studi yang dilakukan Utomo, 2012 mengenai pesindhen menunjukan bahwa dari realitas sinden di kota Kediri, profesi sinden tidak memandang umur dan materi, rata-rata mereka menekuni dunia sinden karena memiliki bakat seni yang kuat di bidang kesenian khususnya kesenian tradisional jawa.

Salah satu sindhen yang sedang naik daun saat ini adalah Dimas Niken Salindri yang berusia setara dengan usia anak Sekolah Dasar. Di usianya yang masih terbilang kecil, dia sudah bisa membawakan lagu dewasa yang terbilang sulit seperti "kutut manggung" dan "pangkur rinoso" bahkan dalam "guyonan" pun juga seperti layaknya orang dewasa. Kemampuan nyindhen sudah ada sejak dia kecil, bahkan sekarang sudah banyak memeriahkan berbagai panggung hiburan dikota maupun luar kota. Serta terdapat beberapa pesindhen muda lain yang bermunculan di kota Kediri mulai dari SMP, hingga pelajar SMA yang banyak menyumbangkan suaranya diberbagai acara. Sebagai palajar semestinya kewajiban yang dilakukan adalah belajar, namun kenyataanya terdapat siswa yang memiliki profesi sebagai pesindhen yang kebanyakan manggung pada malam hari, seharusnya sebagai pelajar dapat belajar dengan baik sesuai tugas perkembangannya. Siswa yang memiliki konsep diri yang positif dalam belajar akan mampu meningkatkan kemampuan dan keterampilannya dalam mengembangkan potensi yang dimiliki serta mampu mengatasi masalah yang dihadapi. Konsep diri dapat diartikan sebagai gambaran atau penilaian seseorang mengenai dirinya sendiri.Konsep diri adalah gagasan tentang diri sendiri yang mencakup keyakinan, pandangan dan penilaian seseorang terhadap dirinya sendiri. Menurut Santrock (2007) konsep diri merujuk pada evaluasi yang menyangkut berbagai bidang-bidang tertentu dari diri.

Seseorang yang memiliki karakteristik konsep diri yang baik akan mampu memahami dirinya sendiri dan dapat membentuk suatu konstruk dalam diri individu. Apabila individu mampu memahami konsep diri positif bagi dirinya, tentunya akan dapat memahami lingkungan sosialnya, dimana lingkungan sosial memiliki pengaruh besar pada perkembangan konsep diri individu. Selain itu, dengan konsep diri yang baik individu dapat menerima keadaan pada dirinya, memiliki pandangan ideal terhadap dirinya, serta mampu berbaur dalam kehidupan sosial bermasyarakat yang berbudaya.

Dari latar belakang permasalahan tersebut, maka peneliti tertarik untuk meneliti tentang konsep diri pada pesindhen pelajar di Kota Kediri. Dengan demikian peneliti tertarik untuk melakukan penelitian yang berjudul " Penelitian Fenomenologi Tentang Konsep Diri Pelajar Yang Berprofesi Sebagai Pesindhen Di Kota Kediri “. Penelitian ini bertujuan untuk mengetahui konsep diri pelajar yang berprofesi sebagai pesindhen dalam memaknai diri(self)nya terhadap profesinya dan lingkungan sosial memaknai pelajar yang berprofesi sebagai pesindhen di Kota Kediri.

\section{METODE}

Penelitian ini adalah penelitian yang besifat kualitatif. Penelitian yang digunakan yaitu penelitian kualitatif deskriptif. Penelitian kualitatif deskriptif adalah berupa penelitian dengan metode atau pendekatan studi kasus (case study). Penelitian ini 
memusatkan diri secara intensif pada satu obyek tertentu yang mempelajarinya sebagai suatu kasus. Data studi kasus dapat diperoleh dari semua pihak yang bersangkutan, dengan kata lain dalam studi ini dikumpulkan dari berbagai sumber. Penelitian studi kasus akan kurang kedalamannya bilamana hanya dipusatkan pada fase tertentu saja atau salah satu aspek tertentu sebelum memperoleh gambaran umum tentang kasus tersebut. Sebaliknya studi kasus akan kehilangan artinya kalau hanya ditujukan sekedar untuk memperoleh gambaran umum namun tanpa menemukan sesuatu atau beberapa aspek khusus yang perlu dipelajari secara intensif dan mendalam. Studi kasus yang baik harus dilakukan secara langsung dalam kehidupan sebenarnya dari kasus yang diselidiki. Walaupun demikian, data studi kasus dapat diperoleh tidak saja dari kasus yang diteliti, tetapi, juga dapat diperoleh dari semua pihak yang mengetahui dan mengenal kasus tersebut dengan baik

Budaya Jawa terkenal akan kesenian yang memiliki harmonisasi instrumen gamelan yang indah serta berkaitan dengan sejarah kerajaan-kerajaan dimasa lalu atau cerita peninggalan nenek moyang. Kebudayaan tersebut bisa dilihat dari berbagai kesenian yaitu wayang kulit, wayang krucil, wayang beber, wayang orang, ludruk, ketoprak, campursari, tayub, jaranan dan masih banyak lagi, semua ini tidak lepas dari seorang penyanyi yang disebut sindhen. Sindhen juga disebut waranggana "wara" berarti seseorang berjenis kelamin wanita, dan "hanggana" berarti sendiri. Sindhen adalah sebutan bagi wanita yang bernyanyi mengiringi orkestra gamelan, mamakai pakaian kebaya lengkap dengan selendang atau orang jawa menyebutnya "sampur" yang umumnya sebagai penyanyi yang serba bisa. Sindhen yang baik harus mempunyai pengetahuan luas dan keahlian vokal yang baik serta kemampuan untuk menyanyikan "tembang" atau lagu. Pada pertunjukan wayang saat ini sindhen bisa mencapai delapan hingga sepuluh orang bahkan lebih untuk pergelaran yang sifatnya spektakuler.

Di wilayah Kediri Jawa Timur profesi sindhen telah ditekuni oleh beberapa wanita muda yang memiliki ketertarikan akan keindahan budaya kesenian jawa, pada umumnya mereka belajar mengembangkan atau menyanyikan lagu jawa yang dilatih oleh seorang dalang pewayangan daerah mereka, dan setelah itu mereka di didik untuk belajar cengkok suara "gendhing" yang terkesan halus dan lembut. Hasil studi yang dilakukan Utomo, 2012 mengenai pesindhen menunjukan bahwa dari realitas sinden di kota Kediri, profesi sinden tidak memandang umur dan materi, rata-rata mereka menekuni dunia sinden karena memiliki bakat seni yang kuat di bidang kesenian khususnya kesenian tradisional jawa.

Salah satu sindhen yang sedang naik daun saat ini adalah Dimas Niken Salindri yang berusia setara dengan usia anak Sekolah Dasar. Di usianya yang masih terbilang kecil, dia sudah bisa membawakan lagu dewasa yang terbilang sulit seperti "kutut manggung" dan "pangkur rinoso" bahkan dalam "guyonan" pun juga seperti layaknya orang dewasa. Kemampuan nyindhen sudah ada sejak dia kecil, bahkan sekarang sudah banyak memeriahkan berbagai panggung hiburan dikota maupun luar kota. Serta terdapat beberapa pesindhen muda lain yang bermunculan di kota Kediri mulai dari SMP, hingga pelajar SMA yang banyak menyumbangkan suaranya diberbagai acara. Sebagai palajar semestinya kewajiban yang dilakukan adalah belajar, namun kenyataanya terdapat siswa yang memiliki profesi sebagai pesindhen yang kebanyakan manggung pada malam hari, seharusnya sebagai pelajar dapat belajar dengan baik sesuai tugas perkembangannya. Siswa yang memiliki konsep diri yang positif dalam belajar akan mampu meningkatkan kemampuan dan keterampilannya dalam mengembangkan potensi yang dimiliki serta mampu mengatasi masalah yang dihadapi. Konsep diri dapat diartikan sebagai gambaran atau penilaian seseorang mengenai dirinya sendiri.Konsep diri adalah gagasan tentang diri sendiri yang mencakup keyakinan, pandangan dan penilaian seseorang terhadap dirinya sendiri. Menurut Santrock (2007) konsep diri merujuk pada evaluasi yang menyangkut berbagai bidang-bidang tertentu dari diri.

Seseorang yang memiliki karakteristik konsep diri yang baik akan mampu memahami dirinya sendiri dan dapat membentuk suatu konstruk dalam diri individu. Apabila individu mampu memahami konsep diri positif bagi dirinya, tentunya akan dapat memahami lingkungan sosialnya, dimana lingkungan sosial memiliki pengaruh besar pada perkembangan konsep diri individu. Selain itu, dengan konsep diri yang baik individu dapat menerima keadaan pada dirinya, memiliki pandangan ideal terhadap dirinya, serta mampu berbaur dalam kehidupan sosial bermasyarakat yang berbudaya. 
Dari latar belakang permasalahan tersebut, maka peneliti tertarik untuk meneliti tentang konsep diri pada pesindhen pelajar di Kota Kediri. Dengan demikian peneliti tertarik untuk melakukan penelitian yang berjudul" Penelitian Fenomenologi Tentang Konsep Diri Pelajar Yang Berprofesi Sebagai Pesindhen Di Kota Kediri “. Penelitian ini bertujuan untuk mengetahui konsep diri pelajar yang berprofesi sebagai pesindhen dalam memaknai diri(self)nya terhadap profesinya dan lingkungan sosial memaknai pelajar yang berprofesi sebagai pesindhen di Kota Kediri.

\section{HASIL DAN PEMBAHASAN}

\section{Deskripsi Setting / Lokasi Penelitian}

Pada penelitian ini terdapat lokasi penelitian yang berbeda-beda pada setiap informan. Karena penelitian dilakukan diluar sekolah, maka peneliti membuat kesepakatan tempat dan waktu penelitian dengan informan untuk melakukan wawancara. Tempat untuk melakukan wawancara kepada informan dipilih berdasarkan situasi dan kenyamanan informan untuk menjawab pertanyaan dari peneliti. Berikut adalah profil informan dan lokasi dimana penelitian dilaksanakan.

\section{Informan Pertama}

Informan pertama berinisial BG, informan pertama ini lahir di Sidoarjo 23 Mei 2001, sekarang dia tinggal di jalan Karyatani Sukorame kecamatan Mojoroto, dan dia adalah salah satu siswi SMA Negeri 1 kota Kediri jurusan IPS kelas 2. Informan pertama cukup lama menekuni profesi sebagai pesindhen, dikalangan para pesindhen BG termasuk sindhen muda yang memiliki suara yang khas, memiliki penampilan yang menarik dan mampu menyanyikan berbagai macam aliran musik. Wawancara kepada informan pertama dilakukan di taman Sekartaji kota Kediri, lokasi ini dipilih berdasarkan kesepakatan informan pertama karena pada hari itu informan akan pergi keluar kota. Dilokasi ini selain tempatnya nyaman hal ini bertujuan agar peneliti dapat menggali informasi yang lebih dalam dari informan sesuai dengan fakta sebenarnya.

\section{Informan Kedua}

Informan kedua berinisial AF, informan kedua ini lahir di Kediri 14 Mei 2001, dan sekarang bertempat tinggal di dusun Sambi Robyong kecamatan Blabak kabupaten Kediri. AF adalah salah satu siswi di SMK Negeri 2 kota Kediri jurusan Akuntansi dan sekarang duduk di kelas 1 yang akan naik ke kelas 2. AF merupakan sindhen yang cukup terkenal diantara seniman di kota Kediri, dia memiliki suara yang khas pada setiap lagu yang dibawakannya, selain itu dia juga sudah banyak meramaikan didunia hiburan jawa di Kediri dan sekitarnya. Wawancara dilakukan sore hari di rumah informan kedua yaitu di dusun Sambi Robyong kecamatan Blabak kabupaten Kediri, lokasi ini dipilih berdasarkan kesepakatan informan kedua karena dilokasi ini selain tempatnya nyaman hal ini bertujuan agar peneliti dapat menggali informasi yang lebih dalam dari informan sesuai dengan fakta sebenarnya.

\section{Informan Ketiga}

Informan ketiga berinisial DN, informan ketiga lahir di Kediri 14 Pebruari 2003, dia tinggal di desa Bakalan, kecamatan Grogol kabupaten Kediri. DN merupakan salah satu siswa dari SMP Negeri 6 kota Kediri. Awal dari profesinya, dia mengikuti ekstra karawitan di sekolahnya, dia dibimbing oleh guru seninya yang juga merupakan seorang sindhen senior di Kediri. Banyak prestasi yang telah diraih oleh DN, salah satunya adalah juara lomba festival sindhen di Surabaya dan menang dalam berbagai lomba lainnya.Wawancara dilakukan sore hari di rumah informan ketiga yaitu di desa Bakalan, kecamatan Grogol kabupaten Kediri, lokasi ini dipilih berdasarkan kesepakatan informan ketiga karena dilokasi ini memudahkan informan untuk menjawab pertanyaan dari peneliti selain itu peneliti juga dapat melakukan observasi dirumah informan agar data yang didapat lebih lengkap dan sesuai fakta sebenarnya.

\section{Informan Keempat}

Informan keempat berinisial IN, informan keempat lahir di Kediri 3 September 2000, tempat tinggal sekarang berada di desa Tinalan gang 1 nomor 42B, kecamatan Pesantren, kota Kediri. IN adalah salah satu siswa kelas XI jurusan Atministrasi Perkantoran di SMK Negeri 2 Kediri. Sebagai pesindhen dia telah banyak mengisi panggung hiburan di Kediri, mulai dari pentas wayang kulit, campursari, karawitan dan pentas seni lainnya. Keterampilan IN sebagai pesindhen didapat dari SMP saat masih kelas VII karena dia mengikuti ekstra seni karawitan disekolahnya. Wawancara dilakukan sore hari di rumah informan keempat yaitu di desa Tinalan gang 1 nomor 42B, kecamatan Pesantren, kota Kediri, lokasi ini dipilih berdasarkan kesepakatan informan keempat, karena dilokasi ini 
memudahkan informan untuk menjawab pertanyaan dari peneliti, selain itu peneliti juga dapat melakukan observasi dirumah informan agar data yang didapat lebih lengkap dan sesuai fakta sebenarnya.

\section{Deskripsi Data Hasil Penelitian}

Dari hasil pengumpulan data dengan teknik wawancara, peneliti menguraikan data yang telah didapat dari lapangan. Data yang telah didapat dari hasil wawancara dipindahkan dalam bentuk transkrip dari bentuk rekaman menjadi bentuk tertulis kemudian direduksi yaitu dirangkum dan memilih hal-hal pokok kemudian dicari polanya. Selanjutnya penyajian data atau display agar memudahkan peneliti dalam memahami apa yang terjadi dan membantu peneliti dalam menjalankan kerja selanjutnya. Kemudian peneliti memasukkan data dari display data ke dalam tabel koding untuk mempermudah peneliti menginterpretasikan situasi dan fenomena yang terjadi. Selain itu, observasi langsung dilakukan agar peneliti mampu memahami konteks data dalam keseluruhan situasi sosial. Hasil observasi kemudian didiskripsikan terhadap apa yang dilihat, didengar, dan dirasakan oleh peneliti. Serta dokumentasi digunakan untuk menemukan buktibukti yang terkait dengan informasi yang telah didapat dari lapangan.

\section{PEMBAHASAN}

\section{Sindhen Pelajar Kota Kediri Memaknai Diri(Self )nya Tentang Profesinya}

Menurut Sagala (2009) mengemukakan bahwa secara tradisional profesi mengandung arti prestise, status sosial dan otonomi yang lebih besar yang diberikan oleh masyarakat kepadanya. Selain itu, profesi berdasarkan kepada keahlian, kompetensi, dan pengetahuan spesialis. Profesi adalah kata serapan dari sebuah kata dalam bahasa Inggris "Profession". Dengan kata lain profesi adalah pekerjaan yang membutuhkan pelatihan dan penguasaan terhadap suatu pengetahuan khusus.Dalam menjalankan profesi tidak ada paksaan dan merupakan kemauan dari diri pribadi. Dari hasil penelitian dilapangan mengenai hal tersebut rata-rata informan menjawab atas inisiatif sendiri, hal ini karena memang mereka suka dan keinginan yang kuat untuk belajar sindhen. Menurut para informan profesi seorang sindhen itu menarik karena sindhen itu adalah sosok wanita yang terus mempertahankan budaya jawa, multitalenta, dan tidak semua generasi muda mampu untuk menjadi seorang sindhen. Selain itu mereka juga bangga dengan seorang sindhen karena sindhen itu wanita jawa yang pandai mengolah suara, berpakaian sopan, mampu mengikuti dalam semua aliran musik, menghibur masyarakat, dan sesorang yang tetap melestarikan budaya jawa. Hal ini berdasarkan hasil penelitian dari salah satu informan yaitu AF yang mengatakan :

" Sindhen itu menurut saya pintar dalam mengolah suara, nada apa saja bisa, sindhen itu kan bisa masuk disemua musik seperti dangdut, pop, keroncong, dan lainnya. Kalau menurut saya ya sindhen itu baguslah intinya, pokoknya idola banget. Karena dari kecil sudah suka jadi lebih menjiwai. “ (AF, 1-6-2018)

Sesuai dengan sifat para wanita jawa pada umumnya yang mempunyai sifat lembut, sopan, dan selalu membawa budayanya kemanapun mereka berada, para informan juga lebih memahami dan mencintai budaya mereka sendiri. Profesi sindhen merupakan profesi yang sulit untuk ditekuni oleh para wanita, tidak semua orang mampu untuk menjadi seorang sindhen, namun hal ini tidak menjadi kendala bagi para informan untuk tetap menekuni profesinya dan mereka merasa nyaman dengan pekerjaannya, hal ini sesuai dengan jawaban dari para informan yang ratarata dari mereka menjawab nyaman dengan profesi yang mereka tekuni karena profesinya merupakan profesi yang positif. Dari profesi yang dijalani, mereka mendapat banyak teman, semakin bertambah pengalaman dibidang seni, dan diusianya yang masih remaja sudah mampu membantu orang tua dalam mendapatkan penghasilan. Pengalaman yang berkesan saat pentas bagi mereka yaitu bertemu dengan idolanya, disaksikan oleh pemerintah dan menang dalam mengikuti berbagai lomba kesenian.

Lingkungan Sosial (Keluarga, Masyarakat, dan Sekolah) Memaknai Sindhen Pelajar Kota Kediri

Menurut Hertati (2009:21) mengatakan bahwa lingkungan sosial merupakan lingkungan pergaulan antar manusia, pergaulan antar pendidik dengan peserta didik serta orang-orang lainnya yang terlibat dalam interaksi pendidikan. Berdasarkan hasil penelitian dilapangan mengenai sikap keluarga ketika mengetahui bahwa mereka adalah seorang pesindhen yaitu, rata-rata mereka menjawab, keluarga sangat mendukung, senang dan bangga dengan profesi yang mereka tekuni. Dukungan dari keluarga sangat 
berpengaruh bagi mereka, secara tidak langsung para informan termotivasi untuk menekuni profesinya, bentuk dukungan yang diberikan keluarga yaitu mulai dari membantu mempersiapkan perlengkapan, membantu menyediakan obat-obatan saat sakit, menemani dan mengantar saat latihan, membantu mencarikan orang yang ahli untuk menimba ilmu, serta memotivasi agar tetap belajar. Dari profesi yang dijalani, mereka dapat membantu kebutuhan ekonomi keluarga. Pengalaman mereka saat bisa membantu kebutuhan ekonomi dari profesi pesindhen, seperti membelikan kebutuhan pokok, mampu mendapatkan uang saku sendiri dan membeli kebutuhan sendiri sehingga tidak merepotkan orang tua.

Selain keluarga juga terdapat lingkungan masyarakat yang berpengaruh dalam kehidupan setiap individu. Lingkungan sosial masyarakat adalah semua manusia yang berada di luar diri seseorang yang dapat mempengaruhi diri orang tersebut, baik secara langsung maupun tidak langsung (Slameto, 2003). Terbentuknya masyarakat karena manusia menggunakan perasaan, pikiran dan keinginannya memberikan reaksi dalam lingkungannya. Dari hasil penelitian mengenai penilaian masyarakat terhadap diri mereka sebagai pesindhen yaitu rata-rata memberikan keterangan bahwa masyarakat sangat mendukung, kagum dengan profesinya, banyak yang tidak percaya dengan usia yang masih duduk dibangku sekolah sudah dapat membantu ekonomi keluarga dengan profesi yang mereka tekuni. Lingkungan yang nyaman akan membuat siapa saja betah tinggal dan berintraksi dengan lingkungannya.

Dari hasil penelitian dilapangan informan memberikan keterangan mengenai kenyamanan mereka dengan lingkungan masyarakat saat mengetahui profesi mereka sebagai pesindhen yaitu rata-rata memberikan keterangan bahwa masyarakat ramah, rukun, menerima dan senang dengan kehadirannya, selalu mendukung mereka menjalankan profesinya, serta mereka selalu menjaga hubungan dengan masyarakat. Dalam menjaga hubungan dengan masyarakat sekitar para informan sering datang ke tetangga untuk ngobrol, saling menyapa saat bertemu, berbaur dengan masyarakat saat ada acara di lingkungan.

Individu yang memiliki kemampuan yang lebih akan mendapat sorotan dari teman-temannya, mulai dari penampilan, gaya berbicara, aksesoris yang dikenakan dan kelebihan yang menonjol dari diri individu tersebut, hal ini menunjukkan citra diri yang terbentuk dari lingkungan mereka bergaul. Menurut Centi (1993), citra diri merupakan salah satu segi dari gambaran diri yang berpengaruh pada harga diri. Sedangkan menurut Pratt (1994) menyebutkan bahwa citra diri adalah bagian dari konsep diri yang berkaitan dengan sifat-sifta fisik. Citra diri dipengaruhi oleh pemikiran mengenai apa yang dimaksud keindahan atau kebugaran dan bentuk tubuh yang ideal menurut seseorang. Berdasarkan hasil penelitian dilapangan mengenai penilaian teman- teman tentang profesi mereka sebagai sindhen yaitu rata-rata merespon baik dan sangat mendukung dengan profesi yang mereka jalani, namun tetap mengingatkan jangan lupa belajar.

Salah satu cara meningkatkan prestasi belajar adalah situasi sekolah yang nyaman, selain itu dukungan dari teman sekolah dan para guru juga membantu dalam meningkatkan prestasi akademik para siswa. Hal ini juga dirasakan oleh para informan yang mengatakan bahwa teman-teman mendukung profesi mereka, membantu jika ada kesulitan belajar, tidak membanding-bandingkan dengan yang lain, senang dengan kehadiran mereka. Respon guru saat mengetahui profesi mereka sebagai pesindhen yaitu rata-rata menjawab para guru bangga dan mendukung karena diusia yang sekarang sudah mampu memperoleh penghasilan sendiri, mampu menyanyikan lagu-lagu jawa yang tergolong sulit, namun juga ada guru yang tidak suka karena profesinya akan mengganggu mereka dalam bidang akademik. Hal seperti yang disampaikan oleh informan ketiga yaitu DN:

"Kalau respon dari guru ada yang suka dan ada yang tidak suka, tapi banyak yang nggak suka karena kata mereka mengganggu pelajaran sehingga saya nggak bisa mengikuti pelajaran, padahal kenyataannya nggak, saya masih bisa mengikuti dan fokus pada pelajaran, tapi kalau menyangkut nilai itu kan tergantung masing-masing kemampuan diri sendiri nggak bisa dipaksa. Kalau guru yang suka itu karena bangga, karena masih kecil sudah bisa bantu orang tua mencari penghasilan, saya bisa menyanyi seperti itu belajarnya gimana apa bakat dari kecil atau memang baru belajar tapi kok sudah seperti semahir itu. " (DN, 3-6-2018)

Hal ini menjadi tugas para guru BK dalam meningkatkan prestasi belajar siswa. Siswa yang memiliki potensi non akademik yang menonjol biyasanya menurun dalam bidang akademiknya, 
untuk itu layanan yang tepat dalam pembelajaran sangat berpengaruh bagi mereka dalam meningkatkan prestasi akademiknya. Menurut Desmita, 2012: 182 ada beberapa strategi yang dapat membantu para guru dalam meningkatkan konsep diri siswa dalam belajar yaitu: 1) membuat siswa merasa mendapat dukungan dari guru, 2) membuat siswa merasa bertanggung jawab, 3) membuat siswa merasa mampu, 4) mengarahkan siswa untuk mencapai tujuan yang realistis, 5) membantu siswa menilai diri mereka secara realistis, serta 6) mendorong siswa agar bangga dengan dirinya secara realistis.

\section{Konsep Diri Sindhen Pelajar Kota Kediri}

Menurut Hurlock (1999), membagi konsep diri menjadi dua bagian yaitu konsep diri sebenarnya/ rill dan konsep diri ideal. Konsep diri sebenarnya ialah konsep seseorang dari siapa dan apa dia itu. Konsep ini merupakan bayangan cermin, ditentukan sebagian besar oleh peran dan hubungan dengan orang lain, dan apa yang kiranya reaksi orang lain terhadapnya. Konsep diri ideal ialah gambaran seseorang mengenai penampilan dan kepribadian yang didambakan. Konsep diri menurut Agustiani (2009), adalah gambaran yang dimiliki seseorang tentang dirinya, yang dibentuk melalui pengalamanpengalaman yang diperoleh dari interaksi dengan lingkungan.

Dari hasil penelitian yang telah dilakukan dilapangan, peneliti menjelaskan tentang konsep diri pelajar yang berprofesi sebagai pesindhen di Kediri. Pada pertanyaan pertama telah dijawab oleh informan yaitu mengenai identitas diri, dan dari keempat informan dapat menyebutkan identitas dirinya yang terkait dengan data diri mereka. Erikson (1989), menurutnya identitas diri adalah kesadaran individu untuk menempatkan diri dan memberikan arti pada dirinya dengan tepat di dalam konteks kehidupan yang akan datang menjadi sebuah kesatuan gambaran diri yang utuh dan berkesinambungan untuk menemukan jati dirinya.Para sindhen pelajar ini rata-rata mempelajari keterampilan sindhen sejak awal masuk SMP mereka sudah mulai belajar sindhen karena memang dari latar belakang keinginan untuk belajar menjadi pesindhen. Terkait dengan pendapat tentang diri mereka sebagai pesindhen rata-rata jawaban mereka yaitu senang saat mereka bisa berkumpul dengan teman-teman sesama profesinya karena mereka ramah, saling mensuport, menambah pengalaman mereka dibidang seni, dapat belajar bersama seniornya, serta mereka dapat meningkatkan kemampuannya dalam mempelajari lagu-lagu baru. Para sindhen pelajar ini merasa bangga dengan diri mereka karena belum tentu semua wanita bisa menjadi seorang sindhen, menurut mereka sindhen itu wanita jawa yang pandai mengolah suara, berpakaian sopan dengan mengenakan kebaya, mampu mengikuti semua aliran musik serta dapat menghibur masyarakat.

Berdasarkana hasil penelitian bahwa mereka bangga dengan profesi yang ditekuni, hal ini karena bahwa dari sindhen dapat membantu kebutuhan keluarga, mendapatkan penghasilan sendiri, dan memiliki kemampuan yang jarang dimiliki oleh orang lain, seperti yang disampaikan oleh informan kedua yaitu AF bahwa:

"Saya bangga karena bisa membantu orang tua, bisa membedakan mana waktunya sekolah dan mana waktunya untuk profesi. “ (AF, 1-6-2018)

Dalam menjalankan profesinya sebagai sindhen, tentunya sudah banyak prestasi yang dicapai terkait dengan profesinya, dalam hal ini termasuk prestasi non akademik yang membanggakan bagi diri mereka. Menurut Mulyono (2008) dalam bukunya prestasi non akademik adalah prestasi atau kemampuan yang dicapai siswa dari kegiatan diluar jam atau dapat disebut dengan kegiatan ekstrakurikuler. Kegiatan ekstrakurikuler adalah berbagai kegiatan sekolah yang dilakukan dalam rangka kesempatan kepada peserta didik untuk dapat mengembangkan potensi, minat, bakat, dan hobi yang dimilikinya yang dilakukan diluar jam sekolah normal. Prestasi yang telah dicapai diantaranya prestasi dalam mengikuti berbagai lomba, festival, pentas bersama idola mereka dan prestasi yang berhubungan dengan profesinya. Dalam belajar pasti para siswa hendaknya menggunakan waktu yang cukup dalam belajar serta gaya belajar untuk meningkatkan konsentras belajar siswa.

Menurut Slameto (2003) belajar merupakan suatu proses usaha yang dilakukan seseorang untuk memperoleh suatu perubahan tingkah laku yang baru secara keseluruhan, sebagai hasil pengalamannya sendiri dalam interaksi dengan lingkungannya.Hal ini bahwa siswa memiliki kebutuhan belajar sendiri yang berbeda satu sama lain, dan memproses dengan cara yang berbeda. Mengenai gaya belajar rata-rata mereka masih bisa belajar dalam situasi apapun dan saat ada jadwal pentas mereka menggantinya 
diwaktu senggang, tapi ada juga beberapa yang membawa buku untuk belajar saat sedang pentas. Saat disekolah mereka menggunakan beberapa alternatif untuk tetap berkonsentrasi dalam belajar diantaranya yaitu belajar bersama teman, mengikuti les dilain waktu sekolah, menggunakan waktu istirahat dengan baik, dan menggunakan cara lain agar tetap berkonsentrasi dalam belajar. Djamarah (2008) mengungkapkan bahwa konsentrasi adalah pemusatan fungsi jiwa terhadap suatu objek seperti konsentrasi pikiran, perhatian dan sebagainya. Dalam belajar dibutuhkan konsentrasi dalam bentuk perhatian yang terpusat pada suatu pelajaran. Ketika ada jadwal pentas dan keessokan harinya mereka sekolah pastinya berpengaruh juga pada kondisi kesehatan, saat sering pentas rata-rata menjaga kesehatan dengan istirahat yang cukup, mengatur pola makan dan perbanyak minum air putih dan minum vitamin, saat pentas selalu membawa obatobatan ringan dan minyak angin.

Manusia diciptakan di dunia ini disertakan dengan kelebihan dan kekurangan. Dalam berbagai bidang pekerjaan tentunya juga banyak ditemukan beberapa kelebihan dan kekurangan pada setiap individu, mengenai kelebihan yang dimiliki oleh para pesindhen, kelebihan yang mereka miliki yaitu mampu menyanyikan lagu dari berbagai aliran musik, memiliki kemampuan menghafal lagu yang cepat dan mudah dalam mempelajari lagu-lagu baru, hal ini menunjukkan para pesindhen ini memiliki kepercayaan diri dalam menjalankan profesinya. Menurut Lauster (2002)menjelaskan bahwa kepercayaan diri merupakan suatu sikap atau keyakinan atas kemampuan diri sendiri sehingga dalam tindakan-tindakannya orang yang bersangkutan tidak terlalu cemas, merasa bebas untuk melakukan hal-hal yang sesuai keinginan dan tanggung jawab atas perbuatannya, sopan dalam berinteraksi dengan orang lain, memiliki dorongan prestasi serta dapat mengenal kelebihan dan kekurangan diri sendiri. Para informan ini juga memiliki kekurangan dalam menjalankan profesinya dan rata-rata informan menjawab kurang mahir dalam berjoget sambil bernyanyi, kurang mahir dalam menyanyikan lagu klasik, hal ini karena usia mereka yang tergolong masih remaja yang masih memiliki rasa malu dalam beraktualisasi didepan masyarakat, dengan belajar lebih giat, lebih banyak latihan, mencari orang yang ahli untuk dijadikan pembimbing akan membantu mereka dalam mengatasi kekurangan pada diri para pesindhen pelajar ini. Menurut Santrock (2007) mengemukakan bahwa salah satu karakteristik remaja pada umumnya yaitu, remaja lebih sadar akan dirinya (selfconscious) dibandingkan dengan anak-anak dan lebih memikirkan tentang pemahaman diri mereka. Remaja lebih introspektif, yang mana hal ini merupakan bagian dari kesadaran diri mereka dan bagian dari eksplorasi diri. Namun introspeksi tidak selalu terjadi ketika remaja dalam keadaan isolasi social, kadang-kadang mereka meminta dukungan dari teman-temannya, meminta opini mengenai definisi diri yang baru muncul.

Sebagai makhluk yang diciptakan dengan fitrohnya, manusia diwajibkan untuk selalu beribadah kepada Tuhannya. Walaupun sedang menjalankan aktifitas bekerja sesorang yang taat untuk beribadah akan selalu menjalankan perintah Tuhan YME, saat sedang pentas para pesindhen ini tidak mengabaikan kewajiban untuk beribadah, mereka selalu menyempatkan untuk beribadah dan jika waktu yang tidak memungkinkan mereka menggantinya diwaktu yang tepat, agar tetap menjaga hubungan dengan Tuhan, hal yang dapat dilakukan yaitu selalu berdo'a ketika akan melakukan apapun, selalu ingat waktu ibadah, membaca surat-surat pendek dan berzikir. Semakin berkembangnya zaman tentunya banyak sekali pengaruh-pengaruh dari budaya asing yang menjadi pengaruh generasi penerus bangsa. Para informan berharap sindhen dimasa depan mampu memahami musik yang lebih mendalam, sindhen semakin banyak generasi penerusnya, sindhen tetap melestarikan dan mempertahankan budaya tradisional jawa.

\section{PENUTUP}

\section{Simpulan}

Berdasarkan hasil penelitian yang telah diperoleh, maka dapat disajikan simpulan sebagai berikut :

Konsep diri sindhen pelajar di kota Kediri merupakan pandangan dan pemahaman mereka terhadap diri sendiri dimana mereka tinggal dan menjalankan profesinya sebagai seorang sindhen Menurut mereka, profesi sindhen merupakan profesi yang unik, sulit untuk ditekuni, dan tidak semua orang mampu untuk menjadi seorang sindhen. Para sindhen pelajar ini menekuni profesinya berdasarkan kemauan diri pribadi serta adanya dorongan untuk belajar seni tradisional oleh karena itu mereka merasa nyaman dan bangga dengan profesinya. 
Walaupun sebagai pesindhen namun tidak lupa dengan kewajiban sebagai seorang pelajar, saat pentas pun mereka tetap bisa belajar dengan gaya belajar masing-masing, serta para sindhen pelajar ini juga menggunakan berbagai cara untuk tetap konsentrasi belajar saat di sekolah.Lingkungan sosial memaknai sindhen pelajar sebagai profesi yang positif. Dukungan masyarakat, teman-teman dan keluarga sangat membantu sindhen pelajar ini untuk meningkatkan prestasi mereka dalam menjalankan profesinya. Lingkungan memandang sindhen pelajar ini dengan kagum dan bangga akan profesi yang jalani, diusia yang masih muda sudah dapat membantu kebutuhan keluarga dan mampu melestarikan budaya tradisional yang sudah hampir terkikis oleh perkembangan zaman.

\section{DAFTAR PUSTAKA}

Agustiani, H. (2009). Psikologi Perkembangan. Jakarta: Aditama.

Centi, P. J. (1993). Mengapa Rendah Diri. Yogyakarta: Kanisius.

Desmita. 2012. Psikologi Perkembangan Peserta Didik. Bandung: Remaja Rosdakarya.

Djamarah, S. B. (2008). Psiologi Belajar. Jakarta: Rineka Cipta.

Erikson, Erick, H. 1989.Identitas dan Siklus Hidup Manusia; Bunga Rampai 1.Penerjemah : Agus Cremers. Jakarta : PT. Gramedia.

Hertati, Diana. 2009. Faktor-faktor yang mempengaruhi potus studi mahasiswa universitas pembangunan nasional veteran Jatim. Surabaya: JIPTUPN.

Hurock, E. (1999). Perkembangan: Suatu pendekatan sepanjang rentang kehidupan. Jakarta: Erlangga.

Lauster, Peter. 2002. Tes Kepribadian (Alih Bahasa: D.H Gulo). Edisi Bahasa Indonesia. Cetakan Ketigabelas. Jakarta: Bumi Aksara.

Mulyono. 2008. Manaemen Admiistrasi \& Organisasi. Jogjakara: Arruz Media.

Pratt, C.A. 1994. A Journal of Nutrition Education Volume 26 Number 2. March. Michigan: Departement of Human Environment.

Sagala, S. H. 2009. Kemampuan Profesional Guru dan Tenaga Kependidikan, Bandung: Alfabeta.

Santrock, W.J. 2007. Remaja Edisi Sebelas(1). Jakarta: Erlangga.
Slameto. 2010. Belajar dan faktor-faktor yang mempengaruhi. Jakarta: PT Rineka Cipta.

Sugiyono. 2013. Metode Penelitian Kuantitatif Kualitatif dan $R$ and D, Bandung: Alfabeta.

Utomo, P. A. 2012. Konsep Diri Shinden Campursari(Studi Fenomenologi Konsep Diri Sinden Campursari Di Kota Kediri). Skripsi. Bandung : Universitas Komputer Indonesia 
Jurnal Bikotetik. Volume 03 Nomor 02 Tahun 2019, 39 - 80 